\title{
Incidence and impact of land conflict in Uganda
}

\author{
Klaus Deininger* \\ and \\ Raffaella Castagnini
}

The World Bank

World Bank Policy Research Working Paper 3248, March 2004

The Policy Research Working Paper Series disseminates the findings of work in progress to encourage the exchange of ideas about development issues. An objective of the series is to get the findings out quickly, even if the presentations are less than fully polished. The papers carry the names of the authors and should be cited accordingly. The findings, interpretations, and conclusions expressed in this paper are entirely those of the authors. They do not necessarily represent the view of the World Bank, its Executive Directors, or the countries they represent. Policy Research Working Papers are available online at http:/lecon.worldbank.org.

*Corresponding author: kdeininger@worldbank.org, Tel 202-473 0430.

We thank the Economic Policy Research Center, in particular Peter Mijumbi and Abby Sebina-Zziwa, for collecting the data and two anonymous referees for very thoughtful suggestions that helped to considerably improve the paper. Support from the Norwegian ESSD Trust Fund (Environment Window) and the Italian Consultant Trust Fund is gratefully acknowledged. 


\title{
Incidence and impact of land conflict in Uganda
}

\begin{abstract}
While there is a large, though inconclusive, literature on the impact of land titles in Africa, little attention has been devoted to the study of land conflict, despite evidence on increasing incidence of such conflicts. We use data from Uganda to explore who is affected by land conflicts, whether recent legal changes have helped to reduce their incidence, and to assess their impact on productivity. Results indicate that female-headed households and widows are particularly affected and that the passage of the 1998 Land Act has failed to reduce the number of pending land conflicts. We also find evidence of a significant and quantitatively large productivity-reducing impact of land conflicts. This suggests that, especially in Africa, attention to land-related conflicts and exploration of ways to prevent and speedily resolve them would be an important area for policy as well as research.
\end{abstract}

Keywords: Conflict; Land, Sustainable land use; Agriculture, Productivity; Gender; Nonparametrics.

\section{Introduction}

A large literature has described causes and impacts of land-related conflicts in countries that inherited a highly unequal distribution of land ownership, such as Brazil, El Salvador, Guatemala, Zimbabwe, and South Africa (Moore 1966, Wickham-Crowley 1991, Kriger 1992). More recently, evidence from these settings has been complemented by increased awareness of the economic and political importance of landrelated conflict even in African countries, such as Rwanda, Burundi (Kairaba 2002), Côte d'Ivoire (Chauveau 2000), and Ghana (Firmin-Sellers 2000), which, with relatively low population density, had traditionally been characterized by relatively egalitarian land access.

One of the main reasons underlying the increased incidence of land conflict in these countries is the failure of the prevailing land tenure systems to respond to the challenges posed by appreciation of land in a way that would enhance effective tenure security and thus provide the basis for higher levels of investment and productivity-enhancing land transfers rather than the dissipation of resources in conflict over land. Such appreciation can come about due to increased population and other exogenous factors including technical change, improved terms of trade for agriculture, or non-agricultural demand for land. Factors that have made an effective response difficult include a lack of clarity about the role of formal and informal institutions in land administration, the limited outreach of the former, and the fact that reaching a consensus on land policies is made difficult by the structural inequalities inherent in these systems, e.g. along gender and ethnic lines. As a result, traditional interventions such as titling, which were very effective in other parts of the world, have proven inadequate in many African contexts where, instead of fostering growth, they may even have led to higher levels of conflict.

The increasingly widespread incidence of land conflicts in Africa is well documented in the literature. It has been shown that even limited land conflicts can erupt into large-scale civil strife and violence (Andre and 
Platteau 1998), especially if "political entrepreneurs" capitalize on the underlying grievances to further their cause (Fred-Mensah 1999, Daudelin 2002). At the same time, there are few detailed studies of conflicts relating to land rather than general conflicts or efforts aiming to separate the impact of changes in the legal framework governing land relations as compared with the myriad of other factors that can have an impact on the incidence of conflict. As a result, it is far from undisputed whether land related conflicts are a serious enough issue to warrant attention by policy makers or outside support. To determine whether this is the case, it is necessary to show that over and above the social problems and direct costs that may be caused by land conflicts, these conflicts affect productivity of land use and thus reduce the scope for future growth.

This paper uses household-level data from Uganda to do so by exploring the economic impact of landrelated conflict, its incidence, and the extent to which recent legal measures have helped to bring about a reduction in land-related conflict. The paper is structured as follows. Section two provides a review of the literature, a discussion of the conceptual framework, the survey methodology and estimation strategy. Section three discusses descriptive statistics on the incidence and possible impact of land conflict. Econometric evidence that accounts for the possibility of conflict being endogenous is provided in section four. Section five concludes and discusses implications for land policy in other countries.

\section{Background and conceptual framework}

While increased population density and demand for land can set in motion a virtuous cycle of increasingly precise definition of property rights, investment, growth, and productivity-enhancing exchange of land, failure to respond with the appropriate institutional innovations can lead to a downward spiral of conflict and strife over a rapidly shrinking overall pie. In this section, we draw on the literature to illustrate some of the underlying factors, highlight how they are operational in the case of Uganda, and on this basis formulate hypotheses and an estimation strategy that will allow us to test these with the data available.

\subsection{Relevance of the issue and key aspects}

Before discussing the case of Uganda in more detail, it will be useful to put land conflict into a broader context of increasing land values and scarcity, and to identify some of the factors that, in African contexts, imply that, instead of leading to successively greater investment and productivity, these result in higher incidence of land-related conflicts.

Property rights to land are not static but constitute a social construct that responds to broader needs and evolves over time (Sjaastad and Bromley 2000). Given its spatial extension, defining property rights to land or to write contracts regarding their exchange is costly. Therefore, boundaries may, at low levels of population density, be defined only loosely, transfers will normally involve only usufruct and not ownership and often be confined to community members, thereby allowing much of the content of land rights and associated transactions to be defined informally by unwritten "custom". Changing economic and social 
conditions that make land more valuable and increase the benefits to be obtained from land transfers imply that the value of attributes which have previously been left undelineated may increase sufficiently to offset the transaction costs associated with more precise delineation of land rights (Barzel 2000).

A key variable that underlies the need for better definition of property rights to land is population growth. Rapid population growth, combined with either limited opportunities for non-agricultural employment or, in other areas, increasing non-agricultural demand for land, is a key factor that causes land values to appreciate, resulting in higher competition for a limited or decreasing amount of land available. This often leads to conflict across generations or ethnic groups, especially in environments where risk is high and land is a key asset and source of livelihood (Zongo 2002). Exogenous factors such as improvements in technology, greater opportunities for integration into the global economy, and better agricultural terms of trade not only reinforce this trend but also imply a greater potential for productivity-enhancing exchange of land through rental and/or sales markets.

All of these factors create an opportunity to establish institutions to better define and enforce property rights that can then form the basis for a virtuous cycle of more secure land rights, higher levels of land-related investments, more productivity-enhancing land transfers, and greater overall productivity (Boserup 1965). In fact, the realization that better defined land rights that can be exchanged at lower cost are a critical element of economic development provided the justification for interventions to title land in many parts of the world. Such interventions had a very positive impact in situations where (i) there was a latent demand for more formal and individualized forms of ownership tenure and greater transferability of land as a way to reduce conflict; (ii) the technical and administrative capacity of state institutions matched the requirements of the improved land tenure system; and (iii) the shift provided gains for all or most of the population and political leaders did not lose (Deininger 2003).

At the same time, if institutions to define and enforce property rights to land in a way that provides the security needed for higher levels of investment and exchange do not emerge, there is considerable scope for increased levels of conflict that will not only undermine private investment but can also lead to dissipation of rents, destruction of assets, and social instability (Grossman and Mendoza 1998). Two factors that are likely to be critical in determining whether higher levels of land scarcity will lead to increased investment or conflict are the nature of pre-existing institutions governing land relations and the ability to cast the need for development of land institutions in terms of a broad consensus on land policy rather than a zero-sum game. In both respects, Africa is at a relative disadvantage. On the one hand, its land institutions are often inadequate for the task at hand. On the other hand, the fact that traditional systems often define land access along lines of ethnicity or gender implies that it is easy to portray land policy as a zero-sum game that is part of a broader political and ethnic struggle.

In much of Africa, formal institutions for land administration were often superimposed on traditional structures without clear delineation of responsibilities and competencies, implying that they tend to lack both 
outreach and social legitimacy. In fact, in a significant number of African countries, formal tenure covers significantly less than $10 \%$ of the area, implying that more than $90 \%$ of land is held under forms of customary tenure without full legal recognition, i.e. de facto outside the realm of the law (Oosterberg 2002). This has led to a situation where, instead of complementing each other, "traditional" and "modern" systems compete, giving those who are affected by conflicts an opportunity to resort to "institutional shopping", i.e. pursue conflicts in parallel through a variety of channels (Firmin-Sellers 2000). Not surprisingly, this greatly increases the number and duration, and often also the impact of land-related conflicts. The limited outreach of formal institutions is particularly detrimental for marginal populations who generally do not have the resources that would be needed to secure their property rights through alternative means (Kevane and Gray 1999). In fact, well-intentioned interventions to improve land tenure may unintentionally have increased conflict and social polarization instead of providing the basis for sustained growth (Atwood 1990, Pinckney and Kimuyu 1994, Platteau 2000).

Even though many African land tenure systems are characterized by very egalitarian land access within any given group, the relative endowments of different groups, as defined on the basis of ethnicity or gender, can differ sharply from each other. If land values increase in an environment where access to land across groups is highly unequal or governed by other factors such as ethnicity, it can give rise to conflicts that run along ethnic lines and spread to areas completely unrelated to land. For example, if, as in much of West Africa, the descendants of migrants can be easily identified as "outsiders", increased land values provide a strong incentive for "locals" to renege on earlier sales contracts. In the case of Cote d'Ivoire, land access is interlinked with questions of nationality and the ability of only nationals to own land, which can give rise to conflicts that extend far beyond the area of land (Lavigne Delville et al. 2002). In Rwanda, where extreme land scarcity coincided with accumulation of land by individuals with access to non-agricultural incomes, this has led to land conflict being one of the principal reasons that finally fed into the outbreak of civil war in 1994 (Andre and Platteau 1998). Although the consequences may be less noticed by the outside world, similar tensions and clan- or ethnically-based conflicts with devastating consequences for those involved, who are often the poorest of the poor, tend to arise at the boundary between herders and sedentary agriculturalists (van den Brink et al. 1995, Ngaido and McCarthy 2002).

Many if not most traditional African land tenure systems put women at a strong disadvantage as far as access to and control of land as well as secure land tenure are concerned. In view of this, the gender-dimension of inequality in land access is increasingly emerging as a key issue in many countries. It is of particular importance in view of evidence suggesting that independent asset ownership can considerably improve women's bargaining power (Schultz 1999). A second area of concern relates to widows and in view of the fact that, under customary law, women have no land rights on their own but are instead to be taken care of by the deceased's kin, something that could imply considerable insecurity of land ownership by this group.

To the extent that land policies reinforce the tendency of greater land scarcity to amplify pre-existing gender, ethnic, or wealth inequalities with respect to land access, they can contribute to a downward spiral of conflict, 
resource degradation, and social strife, with potentially far-reaching implications for natural resource conservation and agricultural productivity. Conflict over land is particularly likely if speculative land acquisition is fuelled by non-agricultural incomes or jeopardizes the function of land as a social safety net and provision for old-age (Lavigne Delville 2000). The socially corrosive and economically deleterious impact of land conflicts on governance at the local level has been described for Malawi (van Donge 1999) as well as Cote d'Ivoire and Ghana (Amanor and Diderutuah 2001, Kasanga and Kotey 2001). The literature also demonstrates that even apparently trivial land conflicts can be kept alive for generations and may suddenly erupt in seemingly unmotivated acts of possibly ethnically motivated violence (Kuran 1993, FredMensah 1999).

To justify action by policy makers, it is necessary to go beyond descriptive evidence and try to quantify the impact of this phenomenon. Surprisingly, even though many studies deal with causes and consequences of land conflict at a descriptive level, we know of no aiming to quantitatively explore this issue or to explicitly explore whether policy interventions have reduced or increased the level of conflict. Doing so for the case of Uganda is the purpose of this study.

\subsection{The Ugandan context}

Uganda is an interesting case to assess the economic impact of land conflict because of the presence of many of the economic and institutional factors which, according to the literature, provide a basis for the emergence of land conflicts and because of recent efforts to establish a new legal framework to reduce such conflicts. While the country shares with other African countries a relatively high level of population growth of $2.9 \%$ in the 1965-1998 period (World Bank 2002) that has led to increased land scarcity, it is also characterized by considerable regional diversity. Population densities vary from 12 per $\mathrm{km}^{2}$ in the North to 282 per $\mathrm{km}^{2}$ in the West (Mugisha 1998). Land tenure arrangements range from customary in most of the North to freehold in the South. Elimination of many forms of implicit and explicit taxation of the agricultural sector in the early 1990s, together with comparatively high levels of economic growth in recent years that resulted in increased demand for land for non-agricultural uses, made productive use of land more rewarding (Blake et al. 2002) and increased the potential benefits from land transactions. Moreover, even though Uganda is one of the first countries that is believed to have successfully contained the further spread of HIV/AIDS, the disease has brought devastation to innumerable families and left a legacy of widows and widowers, orphans and foster children the impact of which on the social fabric has only started to emerge (Ntozi and Ahimbisibwe 1999).

Uganda's economic features are complemented by a number of institutional issues of interest. Starting with the award of huge land areas to absentee landlords by the British in 1900 under freehold (mailo) tenure (Brett 1973), co-existence of a number of tenure systems created considerable scope for overlapping rights to the same plot that could lead to land conflict. The 1975 nationalization of land under Idi Amin added to this complexity. Although it was overturned by the 1995 Constitution, the fact that despite years of intense domestic debate no consensus could be reached on a number of land-related legal issues for them to be 
included in the Constitution illustrates the political sensitivity of the topic. These issues, relating in particular to the nature of tenants' and women's land rights, were to be resolved by a Land Act which was passed in 1998. Although there have been some concerns about this legislation, ${ }^{1}$ the adoption of an ambitious institutional design together with lack of funding implied that little if any, of the infrastructure needed to implement this Act was established (Government of Uganda 1999, Government of Uganda 2003). As a result, institutions that had in principle ceased to exist with the passage of the Act were the only ones available and, at least in some cases, continued to perform their functions due to lack of alternatives, despite their doubtful legal authority, providing a possible source of conflict.

\subsection{Research questions and hypotheses}

We use the example of Uganda to explore three issues, namely (i) who is affected by different types of land conflict; (ii) the extent to which the recently passed land law has helped to reduce what was perceived as very high levels of land-related disputes; and (iii) the extent to which land conflicts have an adverse impact on the productivity of land use. To explore incidence, time variation, and impact of land-related conflict, we formulate three hypotheses that can be explored quantitatively.

First, a key purpose of the new land legislation was to reduce the incidence, duration, and consequences of land-related conflict. The limited extent of implementation (Mijumbi and Sebina-Zziwa 2001) would imply that the reduction in conflicts may have been lower than one would expect otherwise. Still, we expect that, following the passage of the 1998 Act, the level of land-related conflict decreased.

Second, a number of studies have documented the need for comparatively high payments (whether formal or informal) to resolve conflicts and enforce existing legislation, and the fact that women may face a systematic disadvantage (Khadiagala 2001). Traditional inheritance patterns also imply that it is more difficult for females to maintain access to land in case of either divorce or the death of the spouse than it is for men (Ntozi and Ahimbisibwe 1999, Makerere Institute of Social Research 2002). Given greatly increased adult mortality in the context of HIV/AIDS and the disadvantaged position of women as compared to men, it is likely for the incidence of conflict with respect to widows' lands to have increased. Such conflicts will affect economic outcomes as settling disputes is costly and because it is normally not possible to make full productive use of the land, e.g. by renting it out, while a conflict is pending. Case studies support this hypothesis; in fact, in a study conducted in two districts (Luwero and Tororo), 29\% out of a total of 204 widows indicated that property was taken from following the death of their husband, making them four times more susceptible to land grabbing than male widowers (Gilborn et al. 2000). All of this leads us to

\footnotetext{
${ }^{1}$ While the original draft had contained a clause which, through automatic co-ownership of land by both spouses in the household, aimed to significantly strengthen property rights enjoyed by women, this clause was dropped from the final version, leading to concerns that women may be particularly vulnerable, especially in the context of the significantly increased adult mortality caused by HIV/AIDS.
} 
expect that land conflicts will affect women and the poor disproportionately, thus having a negative impact on equity. ${ }^{2}$

Third, even if eventually, somebody involved in a land conflict will be allowed to keep the land, the conflict will have a negative impact on welfare and productivity through a number of channels. All parties involved are likely to have expend significant amounts of time which otherwise could have been used in productive activities in attempts to resolve land conflicts (Berry 1997). Insecurity about the ability to use land in the future reduces incentives to make land-related investments not only by local farmers but also by outside investors and the government (Binswanger et al. 1995, Kasanga and Kotey 2001). Pending conflict may prevent one or two of the parties from accessing the land, thus leaving plots partly or totally uncultivated. It may even be associated with actions to inflict crop damage such as uprooting of perennials. Even the threat of such action will affect incentives for effort supply and thus further reduce productivity. Moreover, conflict and the associated fear of losing land will undermine the functioning of land markets, implying that producers who lack knowledge or resources (e.g. labor) for self-cultivation will be prevented from renting out, and possibly have to leave the plot fallow. This will force those with insufficient resources, e.g. widows who lack family labor or producers with low ability who would be better off in non-agricultural enterprises, to make sub-optimal use of their land thereby depriving them of rental income and leading to socially suboptimal land use. All of these lead us to expect that land-related conflict will be associated with significant economic losses. In addition to pointing out the incidence of land conflicts, a key contribution of this paper is the attempt to provide econometric estimation that can help to quantify the losses incurred due to conflicts on plots that are currently cultivated. ${ }^{3}$

\subsection{Methodological issues and estimation strategy}

To assess the incidence of conflict in a cross sectional context, we use a standard probit equation. Denote plots by $j$ and households by $i$ and let $C_{i j}$ be a dummy variable equal to one if a conflict is pending on plot $j$ owned by household $i$. We hypothesize the plot characteristics $\boldsymbol{Q}_{j}$, household attributes $\boldsymbol{X}_{\mathrm{i}}$, and community characteristics $\boldsymbol{Z}_{\mathrm{i}}$ affect the probability of the plot being affected by conflict Formally, we estimate a probit equation of the form

$$
C_{i j}=\alpha+\beta \boldsymbol{Q}_{j}+\delta \boldsymbol{X}_{i}+\gamma \boldsymbol{Z}+\varepsilon_{i j}
$$

where the coefficient vectors are as defined above and $\varepsilon_{i t}$ is a white noise error term. Key elements in $\boldsymbol{Q}_{j}$ relate to the plot's size, its distance from the homestead, whether it is rented in or held in ownership, and if owned its tenure status (freehold and leasehold or usufruct rights kibanja on mailo or customary land) and the way it was acquired. Household characteristics $\boldsymbol{X}_{\mathrm{i}}$ include the head's age, gender, and marriage status as well as the total wealth owned by the household. As a large literature has shown that more valuable plots are

\footnotetext{
${ }^{2}$ The provision providing for automatic spousal co-ownership of land which, as discussed above, was eventually not included, could possibly have helped to strengthen the position of women even in an environment where titling was largely ineffective because, in order to be covered by this provision, no administrative action such as issuance of a title or updating of registry records is needed.

${ }^{3}$ Given that some of the plots affected by conflict are likely to have been taken out of cultivation something that will constitute a lower bound of the total losses.
} 
more likely to be held under individualized tenure forms, we introduce the mean land price in the village, $\boldsymbol{Z}_{\mathrm{i}}$, to estimate the impact of tenure holding other characteristics constant.

To test whether the passage of the 1998 Land Act has helped reduce the incidence of land conflicts, we use recall data on households' involvement in such conflicts. We divide the data into three separate three-year periods (1999-2001; 1996-1998; and 1993-1995) and let $C_{i j t}$ be a dummy variable that equals one if, during the 3-year period starting in $t$, a conflict was initiated but not resolved on plot $j$ owned by household $i$. Beyond variables included earlier, we add time dummies $T_{1}$ and $T_{2}$ that take a value of one if the observation was from the 1996-1998 or 1999-2001 period and zero otherwise to expand equation (1) as follows:

$$
C_{i j t}=\alpha+\beta \boldsymbol{Q}_{j}+\gamma \boldsymbol{Z}_{i}+\zeta \boldsymbol{X}_{i}+\delta T_{1}+\varphi T_{2}+\varepsilon_{i j t}
$$

where all right hand side variables are defined as above. The coefficients on the two time dummies, $\delta$ and $\varphi$, will indicate the probability that a conflict which could not be resolved during the period had occurred during the 1996-1998 or the 1999-2002 period, as compared to the original 1993-1995 time span. The introduction of two 3-year periods of recall allows to minimize the potential error introduced by recall bias and the hypothesis that the 1998 Land Act accomplished its objective of reducing the incidence of land conflicts then translates into $\varphi<\delta$, which can easily be tested statistically. Other right hand side variables are time invariant plot characteristics as well as other variables for which recall data on the value of the variable at the beginning of the period was available.

To test for the impact of land-related conflict on observed production outcomes, we combine non- and semiparametric evidence with parametric regressions. Non- and semi-parametric methods are appropriate because they provide an opportunity to "let the data speak" and obtain a graphical representation of the possible impact of conflict on productive outcomes without imposing an a priori structure, thereby allowing to capture possible non-linear relationships that may be present in the data. On the other hand, if the underlying assumptions are satisfied, parametric estimation allows to compare results to those obtained by other studies (e.g. with respect to the existence of economies of scale), to obtain a point estimate of the impact, if any, of conflict, and -most importantly- to control for the fact that conflict may not be completely exogenous by using instrumental variable techniques.

The production systems used by rural households in Uganda are characterized by intensive multi-cropping. A production function for physical output of individual crops based would fail to capture the interaction between different crops and thus be seriously mis-specified. Instead, we aggregate total output using prices at the village level, ${ }^{4}$ To obtain a non-parametric estimate of the impact of conflict, we split the sample into conflict-affected and conflict-free plots and then estimate nonparametric regressions for each of the two subsamples. Given that the widely used Nadaraya-Watson estimator suffers from large bias when curves are estimated at a boundary region, we apply a local linear fit using the smoother function developed by Fan

\footnotetext{
${ }^{4}$ We also tried aggregation using national prices but the results did not differ from those obtained with village level prices.
} 
(1992) which is based on the idea of combining local least square regression with nonparametric kernel density estimation. The resulting least squares problem is equivalent to a weighted least squares regression

$$
\sum_{j=1}^{n}\left(Y_{j}-a-b\left(X_{j}-x\right)\right)^{2} K\left(\frac{x-X_{i}}{h}\right)
$$

where $x$ is the point at which the density is calculated, $X_{i}$ is the observed value, $K$ is the kernel function, $h$ is the bandwidth that control for the degree of smoothness of the estimated curve. ${ }^{5}$ We complement this nonparametric analysis with an OLS specification that takes into account a broader set of independent variables by specifying an augmented Cobb-Douglas production function of the form

$$
\boldsymbol{Y}_{j}=\alpha+\beta \boldsymbol{N}_{j}+\gamma \boldsymbol{X}_{i}+\zeta \boldsymbol{Z}_{i}+\delta C_{i}+\varepsilon_{i j}
$$

where $\boldsymbol{Y}_{j}$ is the logarithm of the value of output per acre obtained from plot $j, \boldsymbol{N}_{j}$ denotes physical inputs, $\boldsymbol{X}_{i}$ and $\boldsymbol{Z}_{i}$ are plot and community characteristics, and $C_{i}$ indicates whether the plot was affected by conflict. A reduction of output due to the presence of conflict through any of the channels (e.g. expenses on conflict resolution, inability to use the plot for production or to transfer it to others, destruction of plot-specific assets in the course of the conflict, or a simple disincentive for effort supply and investment) will then translate into $\delta<0$.

Estimates of equation (4) by OLS will be unbiased only if the right hand side variables are exogenous. To allow for the possibility that this may not be the case, we also estimate the relationship using instrumental variable techniques where the observed level of conflict $C_{i}$ is replaced by $c_{i}$, the predicted probability of conflict as derived from a linear probability model, correcting for standard errors. The literature indicates that use of a linear probability model yields consistent estimates of the parameters in question (Angrist 1991, Hoxby 1996). A number of plot as well as household characteristics can provide good instruments that will affect the probability of having a conflict on the plot but not productivity. The former include the plot's distance to the cultivator's homestead and, if it is owned, its tenure status and mode of acquisition. At the household level, the age, sex, and non-agricultural wealth of the owner can also serve as instruments.

\section{Data and descriptive evidence}

Descriptive evidence highlights the incidence and consequences of land conflict: of the households in the sample, about one third lost plots due to land conflict since 1994, more than double the share (15\%) who had engaged in land sales market transactions in the same period. There is weak evidence that land conflict is

\footnotetext{
${ }^{5}$ This smoother has been shown to be superior to all linear smoothers including Nadaraya-Watson and other competing estimators (Fan 1992, Fan and Gijbels 1996) and is an efficient way to correct the undesired effect in regions where data are scarce. In our case $X$, the logarithm of the plot size in acres, is univariate. We used a rule-of-thumb (ROT) bandwidth local polynomial fitting to choose the appropriate bandwidth (Fan and Gijbels 1996). The objective is to find $a$ and $b$ to minimize the function controlling for the sparseness of the data using the nonparametric kernel density.
} 
more frequent on freehold land and less prevalent under customary tenure. Although a much higher share of plots under conflict ( $31 \%$ as compared to $13 \%)$ is cultivated with perennials, the fact that output per acre is less than half of what is obtained on plots without conflict, points to significant contemporaneous losses, something that is confirmed by direct testimony from the households affected by conflict.

\subsection{Sample and methodological considerations}

The scope for standard household surveys to provide information on land conflicts is limited for a number of reasons. First, in view of the fact that land is a key element in households' asset portfolio (about $60 \%$ in Uganda), information on land-related conflicts is very sensitive and therefore unlikely to be divulged immediately to enumerators unfamiliar with the community. In fact, it is widely believed that the incidence of land conflict that is obtained in traditional surveys suffers from serious under-reporting precisely because of the fact that households fear that doing so may negatively affect the outcome. Second, to the extent that land conflict is a comparatively rare event, over-sampling will be required to increase the effective sample size. Third, as plots that have been lost or abandoned due to conflict will not be mentioned unless specifically asked for, both the survey instrument and sample will need to be adapted for this. At the same time, because households remember conflicts for a long time, obtaining retrospective information and probing for institutional issues related to occurrence and resolution of land conflicts, will be possible.

To deal with these issues and explore the incidence and economic impact of land conflicts, a specialized survey was undertaken by the Economic Policy and Research Council (EPRC), jointly with the World Bank, in the second half of 2001. The survey covered 430 households (126 peri-urban and 304 rural ones) in five districts of Uganda, Lira, Mbale, Kibale, Mbarara, and Luwero, to represent the country's main regions. To increase representation of land-related conflicts, information on households' past and current involvement in land conflicts was obtained from key informants at the village level and from official court registers. In each district, half of the sample was then drawn from a list of households who had been affected by land conflicts in the past while the other half was randomly selected from the remainder. Comparing the number of households affected by land-related conflict reveals that, at the time the survey was undertaken, between $2.5 \%$ and $5 \%$ of households in Uganda had a land conflict pending while about the same share had been affected by a conflict during the past 8 years.

The survey elicited information on standard household characteristics such as sources of income, household composition, education, assets, access to credit, and knowledge of the new land law. At the plot level, this was complemented with information on a subjective assessment of soil quality, tenure status, details on any land conflicts in the present or past, land market participation, and agricultural output, in addition to the gender of the owner, the main decision-maker, and the residual claimant on profits from the plot. Information on households' asset endowments was obtained retrospectively for several points in time, specifically at the point of household formation, and in different years starting from 1993, provided that the household had been in existence then. For each conflict, information was obtained on the start date and the 
end (if it was no longer pending) as well as on the reason leading to the conflict and the instance(s) involved in solving it or trying to do so in the case of pending conflicts.

\subsection{Descriptive statistics}

Table 1 provides information on general characteristics of the households included in the sample, about $71 \%$ of which are rural. The mean family size is 8 persons with a head who is 48 years of age old has about 6 years of schooling. About $25 \%$ of households are female headed. with $69 \%$ of female household heads being widows. The data point towards considerable increases in households' asset base, in line with broader growth in the economy. A key indicator of household welfare is the possession of a permanent house which, overall, increased from $24 \%$ in 1993 to $35 \%$ in 2001 . Across regions, one notes that permanent home ownership is much lower in the North and East where in 1993 only $10 \%$ and 18\%, respectively, had a permanent home. This figure increased to $16 \%$ and $26 \%$, respectively, over the period, still much lower than the $50 \%$ for the Center and $44 \%$ for the West observed in 2001. Another indicator of household wealth is ownership of bicycles (59\% in both periods) and radios (64\% in 1993 and 68\% in 2001).

Economic growth appears to have been associated not only with an increase in asset ownership but also with considerable activation of land rental markets, consistent with the greater scope for efficiency-enhancing land transfers that one would expect to be both a cause and a consequence of higher levels of economic development. The share of households participating in these markets in 2001 (7\% leasing in, $4 \%$ leasing out) was more than double of what had been observed in 1993 (3\% leasing in, 2\% leasing out). The share of land leasing was lowest in the West, with less than 3\% even in 2001, compared to the East where, in 2001, 14\% of respondents participated in land rental markets. By comparison, regional differences in the share of producers who had participated in land sales markets are much less pronounced, amounting to $15 \%$ in total or about $2 \%$ per year in almost all regions. The mean area transacted in both rental and sales markets for those who participated was about 1.5 acres.

The potentially far-reaching implications of land conflict are illustrated by the fact that, in our sample, the amount of land that changed hands as a result of conflict is significantly higher than the amount transferred through sales markets. In fact, almost $33 \%$ of producers indicate that they had lost land due to conflict. While the mean amount of land lost in such incidents ( 23 acres) is affected by a few outliers that involved very large amounts of land, even the median which does not suffer from this problem is, with 2 acres, significantly larger than what was transferred on average either in land rental or in land sales markets. This suggests that the incidence and consequences of land conflict warrant more detailed investigation.

The bottom part of Table 1 provides information on households' knowledge regarding the provisions of the 1998 land law. It illustrates that, three years after its passage, such knowledge remained low; only little more than a quarter of the population indicated that they were informed about the law and only one in 10 households knows about it in the Eastern region. At the same time, those who know about the law appear to be relatively well informed about its main aspects: Most are aware of the fact that ground rent is revived, 
that husbands can not sell household land without consent by the spouse, and that 12 years of peaceful occupation entitle a tenant to land ownership, subject to payment of a nominal ground rent. The striking exception relates to co-ownership of land by the spouse, a provision that was eliminated from the draft in the last minute (Bosworth, 2002) and which the majority of respondents still believes to be included in the law. ${ }^{6}$

Basic plot characteristics for the whole nation, individual regions, and for plots currently under conflict as compared to those that are not, are reported in Table 2. Overall, sample households own or cultivate 861 plots with an average size of 5.11 acres, about half of which, with considerable regional variation, are located next to the house. A large percentage (45\%) of plots was inherited, again varying across regions (from $72 \%$ in the North to $23 \%$ in the Center). In the West and the Center, the share of plots acquired through purchase is, with about $50 \%$, greater than the share inherited. Excluding these two regions where mailo tenure is, with $79 \%$ and $41 \%$ of plots, very important, customary tenure is the prevailing tenure regime with $59 \%$ at the national average and $83 \%$ in the East and $77 \%$ in the North, respectively. Concerning the gender dimension of land rights, about $47 \%$ of the plots are owned by the husband alone, less than $10 \%$ by females alone, $21 \%$ jointly by the wife and husband, and another $21 \%$ by others including landlords. This suggests that, at least for the sample considered here, an extension of land ownership rights to women could have amounted to a considerable shift in the gender-distribution of productive assets. Of the plots included in the sample, $31 \%$ are cultivated with perennials and $46 \%$ with annuals with the remainder either being left fallow or utilized for livestock raising.

To gain a first appreciation of the possible impact of conflict, we also present means of the variables mentioned above for plots that were or were not affected by a pending conflict. The most striking finding is that the mean output per acre on plots without conflict is, with US \$201, more than double the US \$ 90 observed on plots affected by conflict. Even though econometric evidence will be required to provide more rigorous support for the hypothesis of an output-reducing effect of conflict, this suggests that, possibly through one or more of the channels discussed earlier, conflict can indeed affect production outcomes. Part of the explanation could be that, consistent with a investment-disincentive effect, the incidence of perennials is significantly higher (48\%) on plots that are not affected by conflict than on those that are (39\%). We also find that the share of mailo plots among those affected by conflict was significantly higher than among those without conflict whereas the opposite was true for plots under customary tenure. The share of plots owned only by a female was higher among those with conflict than those without.

Households' subjective assessment of the impact of conflict on economic outcomes, as reported in the bottom panel of table 3, support this view: ${ }^{7}$ Of the households with plots affected by conflict, only $23 \%$

\footnotetext{
${ }^{6}$ The Government has amended the Land Act in 2003 to deal with the gender issue, suggesting that, at least in Uganda, one of the key policy conclusions from our findings has already been implemented.

${ }^{7}$ As the question on the impact of conflict was open-ended, we had to categorize answers ex post as follows: Social relations were affected where households stated that land conflicts had led to hatred, enmity, and violence, where tenants or landlords fear for their life or are afraid to be killed, where women fear to be bewitched, and where the conflict has led to others grabbing the land. A Contemporaneous economic loss was registered where the respondent indicated that, because of the conflict, they lost all or part of the income from a given piece of land, that they could not access the land, and that they were unable to produce their subsistence (or get cash for essential items such as medicine) or where it is stated that, because of the conflict, land can not be transferred to others. Direct economic costs related to attempt of settling the conflict relate to wasted time, a costly
} 
indicated that this left productive outcomes unaffected while $42 \%$ pointed towards social problems, $25 \%$ towards reduced investment, and $11 \%$ towards a disruption of the production process that led to an economic loss in the same production period as the main negative consequence from the conflict.

Table 3 gives details of conflicts for the 414 plots (or $48 \%$ of the sample) that were, at some point, affected by conflict. Exceeding of boundaries and tenancy are, with $49 \%$ and $36 \%$, the most common reasons for conflict, followed by inheritance (11\%) and conflicts concerning use of public lands (4\%). Most conflicts were between neighbors (48\%) and family (29\%). Landlord-tenant issues (18\%) and conflicts with government (5\%) are of lesser importance nationally, although, due to the prevalence of mailo tenure, they are of greater relevance in the Center where they accounted for $49 \%$ of the total. Slightly more than a quarter of conflicts started in the $1996-98$ period, $31 \%$ before 1996 , and $43 \%$ after 1999 . Contrary to what one might expect from anecdotal accounts of communities being able to sort out land conflicts among themselves, the majority of such incidents $(76 \%)$ was resolved by formal rather than by informal means, a share that was particularly high during the $1996-98$ period $(80 \%)$. In addition, it is surprising to find that, for more than three quarters of conflicts, formal institutions are the first ones to be approached by the parties involved. The average conflict had a duration of 3.5 years, with family conflicts being shorter ( 2.5 years) and landlordtenant cases, as well as those involving government, extending for almost 5 years on average. Concerning the evolution of conflict types over time, one notes a slight increase in the incidence of tenancy-related conflicts and a small decrease in those related to boundaries.

\section{Econometric results}

Applying the analytical framework outlined earlier to the Ugandan data allows us to obtain three main results. First, we find that female-headed households are significantly more likely to be affected by conflict than are male-headed ones; the probability of having a conflict is $14 \%$ higher for a household headed by a widow and $48 \%$ higher for one headed by a separated woman than for a male-headed household. Second, and contrary to what was intended, the 1998 Land Act did not lead to a decrease in the number of landrelated conflicts, suggesting that either further adjustment of the legal and regulatory framework or greater efforts at dissemination and implementation (or both) will be needed to realize the potential of this piece of legislation. Finally, clear evidence of significant and quantitatively large productivity losses due to land conflict suggests that measures to reduce the incidence of conflict can have a significant impact on the productivity of the agricultural sector, in addition to the contribution such a measure is likely to make to broader and more inclusive rural growth.

process that forced households to incur debts, and indirect costs incurred through action (e.g. poisoning cows or destroying perennials) by others as the conflict escalates. Finally, an investment effect is registered where households fear to be evicted from the plot any time and thus not build permanent structures or make other land-attached investments. 


\subsection{Incidence and frequency of conflicts}

Table 5 presents results from the cross sectional analysis of determinants for contemporaneous conflict (equation 1). The first two columns refer to the cross section where the dependent variable is a dummy taking a value of one if the plot was affected by a conflict that started after 1998 and was still pending in 2001. We note a number of results of interest. Lands under customary tenure are significantly less likely to be affected by dispute; their probability of having conflict is $11 \%$ lower than that of otherwise identical plots. To address concerns that this result may be due to the lower values of customary lands which are normally located farther from infrastructure and may be of lower quality, we include the median land price per acre in the village to capture these effects. One possible explanation for this is that, in many instances, customary arrangements continue to function well and allow quick resolution of conflicts at the local level, similar to what is observed in other countries (Lavigne-Delville 2002).

Home plots are also less likely to be affected by conflict; the point estimate for the coefficient indicates a probability of conflict for such plots that is lower by $17 \%$, other things constant, than on others. One of the reasons for this result could be that continued occupation makes it more difficult to dispute a household's ownership of a given plot, in addition to the fact that equity concerns would make it more difficult to dislodge a household from the home plot. Interestingly, other plot characteristics, including plot size, type of acquisition, and -most surprisingly- the length of previous plot ownership, are not significant determinants of a plot's conflict status.

Concerning the gender dimension of land conflicts and land rights, we note that, everything else constant, the probability of female headed households to be affected by a land conflict is about $11 \%$ higher than that of households headed by a male. To explore possible channels of transmission, we further distinguish between female heads who are married, separated, and widowed. Column 2 of table 3 illustrates that, whereas being a married female head (e.g. due to migration of the husband) does not increase the probability of having a land conflict, widows are $14 \%$ and separated women $48 \%$ more likely to have a land conflict. Although the magnitude of the coefficient on separated females may partly be endogenous if women separate from their husband because of conflicts over land, this is not a concern in the case of widows. It implies that, in an environment where HIV/AIDS-related mortality is high, measures to increase widow's tenure security (and that of women in general) will be especially important.

The fact that the age of the household head is negatively related to the probability of having conflict suggests that generational transition, possibly but not necessarily related to formal inheritance, makes it more likely for a plot to be affected by conflict. In this context, it is not surprising to find that the probability of having a land conflict decreases significantly with age. One reason could be that young people are more likely to be involved in inheritance-related disputes with their parents whose probability of being alive is inversely related to the age of their children. Also, older people may have higher standing in the community, thus decreasing the likelihood of being involved in land disputes. 
Columns 3 and 4 of table 5 report the results of estimating equation (2) where the dependent variable, $C_{i j t}$, is a dummy variable that equals one if a conflict on plot $j$ owned by household $i$ was initiated but not resolved during the 3-year period starting in $t(1993,1996$, or 1999). Using only conflicts that could not be resolved within the time period under concern helps not only to make the dependent variable consistent over time but is also in line with the literature on recall bias which shows that people tend to forget temporary events of relatively short duration as the length of the recall period increases (Pierret 2001). After stacking the data and taking out plots that had been affected by conflict in earlier periods, we obtain a pooled sample of 1515 plots. As few of the right hand side variables of interest are available for the earlier periods, we estimate two equations, one based on the assumption that there was no change in the household head and that the relative level of land prices across the villages did not change over time (column 3) and one that dispenses with this assumption (column 4). ${ }^{8}$ In both cases, results for changes over time in the probability of having conflict on the plot are similar: Compared to the 1993-95 base period, the probability of emergence of a conflict that could not be resolved within the same 3-year period was 5\% higher in 1996-98 and more than 16\% higher in 1999-2001. Tests for equality of the two parameters $\varphi$ and $\delta$ allow us to reject the hypothesis of equality of the conflict probability over time and lead us to conclude that there had been an increase in the level of conflict over time. Although it is impossible to link this to the passage of the Land Act, this provides strong evidence in favor of the hypothesis that, contrary to its intention, the Land Act did not help to reduce the incidence of land-related conflicts.

\subsection{Productivity impact of conflicts}

Even though the above evidence could be enough reason to make land conflicts of concern to policy makers, it will be of interest to quantify their impact on productive outcomes. Figure 1 illustrates the results of nonparametric regressions of output on plot size separately for plots with conflict (solid line) and without conflict (dashed line) Output for plots affected by conflict is clearly lower than for those not affected. In the interval where the majority of data points are located, confidence bands for the two regression functions do not overlap, suggesting that the curves are statistically different from each other. ${ }^{9}$ This implies that plots without conflicts are characterized by higher productivity along the whole range of the land distribution.

To explore the shape invariance of the regression functions, we test for equality of the nonparametric regression functions (Yatchew 1999, Perali 2003). Using 637 plots without and 179 plots with a pending conflict (20 plots with conflict did not have any output), and with a differencing-order of 1 , the applicable Ystatistic is 2.64 , rejecting the hypothesis of equality for plots with and without conflict, implying that they are shape variant. A generalized version of the partial linear model (GPLM) was tested against the parametric generalized linear model (GLM). The test did not reject the GLM specification, implying that a linear specification appropriate explains the data. As this implies that the semi-parametric results are

\footnotetext{
${ }^{8}$ As more than half of the female headed household heads were widows and no data on the death of their husband was available, we omitted the variables related to the gender of the household head. Unfortunately, information about the household head was not asked retrospectively we do not know if the female-head was present in all of the periods or if the separation or the death of the husband has occurred in a particular period.

${ }^{9}$ The confidence bands was obtained bootstrapping the locally weighted regressions 150 times.
} 
consistent with those obtained by OLS, we do not report them (they are available from the authors upon request) and proceed directly to a discussion of the parametric estimates.

Results from parametric estimation, using both OLS and IV, are reported in table $5 .{ }^{10} \mathrm{We}$ find that, after controlling for other factors, output on a plot affected by conflict is significantly below what would be obtained without conflict. More importantly, and consistent with the order of magnitude of losses that emerged from descriptive evidence, the coefficients point to a large reduction in output due to conflict. While the point estimate for the magnitude of this reduction is 0.33 according to the OLS estimates, it is 2.3 in the case of the IV estimates. The IV results also point towards a lower reduction in output through conflicts on public lands (0.46) and those related to tenancy (1.15). To put this into perspective, recall that, based on our sample, the estimated frequency of land conflicts in the total population is between $2.5 \%-5 \% .{ }^{\prime \prime}$ Using the IV estimates, this would imply a conflict-induced loss of agricultural production of between 5.5\% and $11 \%$. As it does neither consider other outlays (e.g. administrative expenses or the destruction of assets) that may be associated with the conflict nor make adjustments for the fact that plots lost due to conflict may not be under production at all, this figure is likely to constitute a lower bound for the true losses. From a policy perspective, this implies that dealing with land conflict can have significant impacts on productivity.

A second finding of considerable interest is that the coefficient on land owned is negative, pointing towards an inverse relationship between farm size and productivity, something that has been hypothesized a long time ago (Bhalla and Roy 1988) and in the meantime been supported by a large literature (Deininger and Feder 2001). While it has repeatedly noted that controlling for soil quality may weaken this relationship (Frisvold 1994, Benjamin 1995), the fact that the coefficient remains negative even once soil quality is controlled for adds to the empirical evidence in this regard (Deininger 2003). While a more in-depth investigation of this issue would transcend the scope of this paper, it does suggest that, in the case of Uganda, increasing farm sizes will not automatically lead to greater productivity and that further exploration of the underlying factors may be an important area for future research.

Coefficients on other variables of interest are in line with expectations: Ownership of livestock, both cattle and pigs, has a strongly output-enhancing effect that is most likely to come about through the ability to use the associated manure, in line with the very limited use of inputs which is consistent with the broader situation in Uganda (Deininger and Okidi 2001). Bad soil quality reduces output by about 27\%. In addition to the coefficients on the regional dummies, which are significantly higher for the West and the Center where coffee is grown than for the East and the North, having coffee on a plot is estimated to increase output by about $27 \%$ in the OLS regression.

\footnotetext{
${ }^{10}$ Note that, if some plots are not cultivated because of conflict (as is indeed suggested by the descriptive evidence), the impact estimated here is a lower bound for the true value given that plots without output are not included in the production function estimation. In view of the limited number of plots per households and the fact that conflict is often household-rather than plot specific, it was impossible to use a regression with household fixed effects.

${ }^{11}$ Note that this is consistent with evidence from the National Household Survey where, to overcome some of the difficulties discussed earlier, information on land conflicts was obtained only at the community level. Results from this survey indicate that two thirds of communities were affected by land conflicts but the number of conflicts reported per community was relatively low.
} 


\section{Conclusion and policy implications}

The fact that a large number of studies on the impact of land titling in Africa have found, at best, mixed results has two possible explanations. One possibility is that measures to improve tenure security are, in the context of Africa, indeed unimportant (Pinckney and Kimuyu 1994). Alternatively, tenure security may be of great relevance but the interventions pursued by governments to increase such security may have been largely ineffective. The only way to distinguish between these two hypotheses is to use a measure of tenure security, such as conflict that can be observed, and test whether such a measure has a discernible impact on observed production outcomes.

In this paper, we conduct such a test for the case of Uganda. The fact that parametric and nonparametric analysis point toward a significant impact of conflict on agricultural output suggests that tenure security is of considerable economic importance. The estimated magnitude of contemporaneous productivity losses due to land conflict, between $5 \%$ and $11 \%$, is very large, though in line with descriptive evidence that points toward a number of ways in which land conflicts lead to economically highly disruptive consequences. This suggests that the limited effectiveness of past interventions may have to do more with the fact that they failed to effectively provide tenure security within a complex institutional environment than with the lack of importance of tenure security per se.

For the case of Uganda, our results imply that greater attention to land conflicts would be warranted. First, the secular trends that underlie the high incidence of land-related conflicts (i.e. appreciation and increased scarcity of land due to population growth, non-agricultural demand, development of the off-farm sector, and HIV/AIDS) are unlikely to be reversed in the short to medium term. Second, we find negative equity consequences from land conflict in the sense that households headed by females and widows, who are likely to be highly vulnerable economically, face a higher probability of land conflict than others. Finally, government interventions that have aimed to reduce land conflict in the past do not seem to have been effective and, by de facto eliminating the institutions that had traditionally dealt with conflict without establishing new ones to take their place, may even have helped to increase the overall incidence of conflict, in addition to the possibility that the lack of attention to women's rights may have made it more difficult for widows to avoid inheritance-related conflicts.

Our results imply that, in Uganda, land-related conflicts have a negative impact on productivity as well as equity. While further study of this issue in other countries would be desirable, the fact that other African countries are equally affected by the secular forces and the institutional inadequacies characterizing Uganda suggests that this is not an isolated case, a hypothesis that is supported not only by an increasing literature on land conflict but also the fact that a large number of African countries have recently started to reform their legal systems (Alden-Wily 2002). The fact that, in Uganda, legal changes aiming to reduce the incidence and impact of conflict did not automatically result in success implies that, in order to be effective, such legal initiatives need to be complemented by effective implementation. The evidence of a significant and 
quantitatively large output-reducing impact of land conflict emerging from our sample, over and above the social tensions that are associated with it, implies that, even if implementation will require some effort, expending this effort is likely to be justified, both from an economic and a social perspective. 
Table 1: General characteristics of the sample

\begin{tabular}{|c|c|c|c|c|c|}
\hline & Total & North & East & Center & West \\
\hline \multicolumn{6}{|l|}{ Household characteristics } \\
\hline Family size & 8.45 & 9.15 & 7.65 & 7.77 & 8.79 \\
\hline Age of head & 48.36 & 46.25 & 51.55 & 49.06 & 47.53 \\
\hline Head's education (years) & 5.82 & 6.87 & 5.29 & 5.49 & 5.66 \\
\hline Female headed & $25.35 \%$ & $26.09 \%$ & $25.58 \%$ & $26.83 \%$ & $24.12 \%$ \\
\hline Rural & $70.70 \%$ & $68.48 \%$ & $66.28 \%$ & $73.17 \%$ & $72.94 \%$ \\
\hline Have a plot affected by conflict now & $23.11 \%$ & $11.67 \%$ & $11.21 \%$ & $30.97 \%$ & $36.82 \%$ \\
\hline Have a plot affected by conflict in the past & $24.97 \%$ & $34.01 \%$ & $18.97 \%$ & $17.41 \%$ & $27.80 \%$ \\
\hline \multicolumn{6}{|l|}{ Asset endowments } \\
\hline Permanent house in 1993 & $23.67 \%$ & $9.88 \%$ & $18.42 \%$ & $37.33 \%$ & $27.08 \%$ \\
\hline Permanent house in 2001 & $35.35 \%$ & $16.30 \%$ & $25.58 \%$ & $50.00 \%$ & $43.53 \%$ \\
\hline Bicycle owned in 1993 & $58.78 \%$ & $62.96 \%$ & $27.63 \%$ & $84.00 \%$ & $59.72 \%$ \\
\hline Bicycle owned in 2001 & $58.84 \%$ & $71.74 \%$ & $31.40 \%$ & $73.17 \%$ & $58.82 \%$ \\
\hline Radio owned in 1993 & $63.66 \%$ & $44.87 \%$ & $52.06 \%$ & $73.97 \%$ & $74.65 \%$ \\
\hline Radio owned in 2001 & $68.37 \%$ & $53.26 \%$ & $53.49 \%$ & $79.27 \%$ & $78.82 \%$ \\
\hline Land owned in 1993 (acres) & 4.58 & 4.40 & 3.40 & 5.15 & 5.01 \\
\hline Land owned in 2001 (acres) & 4.76 & 4.11 & 2.89 & 5.83 & 5.56 \\
\hline \multicolumn{6}{|l|}{ Land market participation } \\
\hline Leasing land in, 1993 & $3.19 \%$ & $3.70 \%$ & $5.26 \%$ & $4.00 \%$ & $1.39 \%$ \\
\hline Area leased in, 1993 (acres) & 1.31 & 1.42 & 1.19 & 0.92 & 2.00 \\
\hline Leasing land in, 2001 & $7.44 \%$ & $8.70 \%$ & $13.95 \%$ & $9.76 \%$ & $2.35 \%$ \\
\hline Area leased in, 2001 (acres) & 1.49 & 1.59 & 1.02 & 1.16 & 3.38 \\
\hline Sold land since 1994 & $14.65 \%$ & $14.13 \%$ & $15.12 \%$ & $12.20 \%$ & $15.88 \%$ \\
\hline Area sold (acres) mean & 3.94 & 2.77 & 2.31 & 4.21 & 5.19 \\
\hline Area sold (acres) median & 1.5 & 1 & 2 & 2.8 & 1.75 \\
\hline Lost land since 1994 due to conflict & $31.16 \%$ & $31.52 \%$ & $46.51 \%$ & $24.39 \%$ & $26.47 \%$ \\
\hline Area lost (acres) mean & 22.99 & 3.78 & 3.94 & 19.74 & 53.75 \\
\hline Area lost (acres) median & 2 & 1 & 2 & 2 & 2 \\
\hline Number of plot lost per household (conditional) & 1.45 & 1.34 & 2.03 & 1.15 & 1.13 \\
\hline \multicolumn{6}{|l|}{ Knowledge about the land law and its provisions } \\
\hline Husband knows about'98 law & $26.5 \%$ & $30.4 \%$ & $10.5 \%$ & $24.4 \%$ & $33.5 \%$ \\
\hline Land belongs to the People & $23.7 \%$ & $25.0 \%$ & $10.5 \%$ & $20.7 \%$ & $31.2 \%$ \\
\hline Ownership after 12 years tenancy & $19.3 \%$ & $22.8 \%$ & $4.7 \%$ & $18.3 \%$ & $25.3 \%$ \\
\hline Co-ownership of spousal land & $4.6 \%$ & $5.4 \%$ & $2.3 \%$ & $3.7 \%$ & $5.9 \%$ \\
\hline Payment of ground rent & $13.5 \%$ & $20.7 \%$ & $0.0 \%$ & $19.5 \%$ & $13.5 \%$ \\
\hline Consent clause for sale of family land & $23.7 \%$ & $29.4 \%$ & $10.5 \%$ & $19.5 \%$ & $29.4 \%$ \\
\hline Compensation on eviction & $22.8 \%$ & $28.3 \%$ & $8.1 \%$ & $18.3 \%$ & $29.4 \%$ \\
\hline Certificates for bibanjia holders & $20.9 \%$ & $26.1 \%$ & $5.8 \%$ & $19.5 \%$ & $26.5 \%$ \\
\hline Number of households & 430 & 92 & 86 & 82 & 170 \\
\hline
\end{tabular}

Source: Own analysis based on the 2001 EPRC/World Bank survey. 
Table 2: Plot characteristics

\begin{tabular}{|c|c|c|c|c|c|c|c|}
\hline & Total & North & East & Center & West & $\begin{array}{l}\text { Conflict } \\
\text { pending }\end{array}$ & $\begin{array}{l}\text { No conflict } \\
\text { pending }\end{array}$ \\
\hline Number of plots & 861 & 197 & 232 & 155 & 277 & 199 & 662 \\
\hline House plot or adjacent & $49.70 \%$ & $52.31 \%$ & $62.50 \%$ & $47.65 \%$ & $37.83 \%$ & $26.67 \%$ & $52.46 \%$ \\
\hline Plot size & 5.11 & 4.62 & 3.66 & 6.58 & 5.85 & 5.06 & 5.26 \\
\hline \multicolumn{8}{|l|}{ Mode of acquisition } \\
\hline Bought & $39.55 \%$ & $19.47 \%$ & $38.10 \%$ & $49.31 \%$ & $49.63 \%$ & $44.21 \%$ & $38.18 \%$ \\
\hline Inherited & $44.80 \%$ & $72.11 \%$ & $52.81 \%$ & $22.92 \%$ & $30.52 \%$ & $36.32 \%$ & $47.3 \%$ \\
\hline Gift & $7.77 \%$ & $2.63 \%$ & $6.93 \%$ & $11.81 \%$ & $9.93 \%$ & $7.89 \%$ & $7.73 \%$ \\
\hline Other (incl. recent settlement) & $7.88 \%$ & $5.79 \%$ & $2.17 \%$ & $15.97 \%$ & $9.93 \%$ & $11.58 \%$ & $6.8 \%$ \\
\hline \multicolumn{8}{|l|}{ Tenure status } \\
\hline Mailo & $27.57 \%$ & $1.16 \%$ & $8.73 \%$ & $78.63 \%$ & $40.54 \%$ & $40.52 \%$ & $24.19 \%$ \\
\hline Freehold & $3.11 \%$ & $1.74 \%$ & $0.87 \%$ & $7.69 \%$ & $4.05 \%$ & $5.88 \%$ & $2.39 \%$ \\
\hline Leasehold & $6.89 \%$ & $15.70 \%$ & $6.55 \%$ & $0.00 \%$ & $4.05 \%$ & $4.58 \%$ & $7.50 \%$ \\
\hline Customary/public & $58.51 \%$ & $77.33 \%$ & $82.97 \%$ & $11.97 \%$ & $43.24 \%$ & $43.14 \%$ & $62.52 \%$ \\
\hline Renting & $3.92 \%$ & $4.07 \%$ & $0.87 \%$ & $1.71 \%$ & $8.11 \%$ & $5.88 \%$ & $3.41 \%$ \\
\hline \multicolumn{8}{|l|}{ Ownership } \\
\hline Male only & $46.81 \%$ & $45.18 \%$ & $51.72 \%$ & $38.07 \%$ & $48.74 \%$ & $41.71 \%$ & $48.34 \%$ \\
\hline Female only & $9.76 \%$ & $6.60 \%$ & $11.64 \%$ & $4.52 \%$ & $13.36 \%$ & $15.58 \%$ & $8.01 \%$ \\
\hline Male and female joint & $21.14 \%$ & $13.71 \%$ & $25.00 \%$ & $21.94 \%$ & $22.74 \%$ & $20.10 \%$ & $21.45 \%$ \\
\hline Landlord & $16.96 \%$ & $25.38 \%$ & $10.78 \%$ & $26.45 \%$ & $10.83 \%$ & $2.01 \%$ & $3.63 \%$ \\
\hline Other (incl. relatives) & $5.34 \%$ & $9.13 \%$ & $0.86 \%$ & $9.03 \%$ & $4.34 \%$ & $17.59 \%$ & $16.77 \%$ \\
\hline \multicolumn{8}{|l|}{ Main crop and output value } \\
\hline Plot cultivated with perennials & $31.13 \%$ & $12.69 \%$ & $47.41 \%$ & $32.26 \%$ & $29.96 \%$ & $39.20 \%$ & $48.19 \%$ \\
\hline Plot cultivated with annuals & $46.11 \%$ & $73.10 \%$ & $36.21 \%$ & $40.00 \%$ & $38.63 \%$ & $28.14 \%$ & $32.02 \%$ \\
\hline Plot left fallow & $1.05 \%$ & $1.02 \%$ & $1.29 \%$ & $1.29 \%$ & $0.72 \%$ & $1.51 \%$ & $0.91 \%$ \\
\hline Output per acre (US \$) & 175 & 180 & 352 & 79 & 77 & 90 & 201 \\
\hline \multicolumn{8}{|c|}{ Impact of conflict (plots w conflict) } \\
\hline No impact mentioned & $22.62 \%$ & $22.22 \%$ & $18.92 \%$ & $27.59 \%$ & $38.89 \%$ & & \\
\hline Social problems & $41.97 \%$ & $48.15 \%$ & $44.60 \%$ & $31.03 \%$ & $27.78 \%$ & & \\
\hline Contemporary economic loss & $10.82 \%$ & $6.17 \%$ & $13.51 \%$ & $13.79 \%$ & $0.00 \%$ & & \\
\hline Reduced investment & $24.59 \%$ & $23.46 \%$ & $22.97 \%$ & $27.59 \%$ & $33.33 \%$ & & \\
\hline
\end{tabular}

Source: Own analysis based on the 2001 EPRC/World Bank survey. 
Table 3: Conflicts and their characteristics (Total number of plots: 861)

\begin{tabular}{|c|c|c|c|c|c|c|c|c|}
\hline & \multirow[b]{2}{*}{ Total } & \multirow[b]{2}{*}{ Family } & \multirow[b]{2}{*}{ Neighbors } & \multirow[b]{2}{*}{$\begin{array}{c}\text { Landlord- } \\
\text { Tenant }\end{array}$} & \multirow[b]{2}{*}{ Government } & \multicolumn{3}{|c|}{ Conflict started } \\
\hline & & & & & & $\begin{array}{c}\text { Before } \\
1996\end{array}$ & 1996-98 & $699-2001$ \\
\hline Plots ever affected by conflict & $48.08 \%$ & $28.74 \%$ & $48.31 \%$ & $18.36 \%$ & $4.59 \%$ & $30.92 \%$ & $25.85 \%$ & $43.24 \%$ \\
\hline Distribution of conflict & 414 & 119 & 200 & 76 & 19 & 128 & 107 & 179 \\
\hline \multicolumn{9}{|l|}{ Conflict characteristics } \\
\hline Share resolved & $51.93 \%$ & $57.98 \%$ & $56.00 \%$ & $36.84 \%$ & $31.58 \%$ & $50.78 \%$ & $60.75 \%$ & $47.49 \%$ \\
\hline Through formal means & $75.98 \%$ & $63.03 \%$ & $83.33 \%$ & $79.45 \%$ & $66.67 \%$ & $66.15 \%$ & $80.00 \%$ & $65.89 \%$ \\
\hline \multicolumn{9}{|l|}{ Reason for conflict } \\
\hline Inheritance & $10.87 \%$ & $35.29 \%$ & $1.50 \%$ & $0.00 \%$ & $0.00 \%$ & $9.38 \%$ & $14.02 \%$ & $10.06 \%$ \\
\hline Exceeding boundaries & $49.28 \%$ & $25.21 \%$ & $73.00 \%$ & $30.26 \%$ & $26.32 \%$ & $50.00 \%$ & $52.34 \%$ & $46.93 \%$ \\
\hline Tenancy & $35.51 \%$ & $35.29 \%$ & $24.50 \%$ & $61.84 \%$ & $47.37 \%$ & $32.81 \%$ & $33.64 \%$ & $38.55 \%$ \\
\hline Public land & $4.35 \%$ & $4.20 \%$ & $1.00 \%$ & $7.90 \%$ & $26.32 \%$ & $7.81 \%$ & $0.00 \%$ & $4.47 \%$ \\
\hline Length (including unresolved ones) & 3.49 & 2.44 & 3.55 & 4.54 & 4.89 & 8.05 & 2.47 & 0.86 \\
\hline
\end{tabular}

Source: Own analysis based on the 2001 EPRC/World Bank survey. 
Table 4: Factors affecting the probability to have a conflict on plot

\begin{tabular}{|c|c|c|c|c|}
\hline & \multicolumn{2}{|c|}{ 1999-2001 period } & \multicolumn{2}{|c|}{ Pooled data } \\
\hline & (1) & $(2)$ & (3) & (4) \\
\hline Land price per acre by village (log) & $\begin{array}{l}0.002 \\
(0.17)\end{array}$ & $\begin{array}{l}0.002 \\
(0.20)\end{array}$ & $\begin{array}{l}0.002 \\
(0.42)\end{array}$ & \\
\hline Tenure status: Kibanja on customary (Dummy) & $\begin{array}{c}-0.100^{*} \\
(2.52)\end{array}$ & $\begin{array}{c}-0.089^{*} \\
(2.27)\end{array}$ & & \\
\hline Tenure status:Kibanja on Mailo (Dummy) & $\begin{array}{l}-0.008 \\
(0.19)\end{array}$ & $\begin{array}{l}-0.001 \\
(0.02)\end{array}$ & & \\
\hline Age of household head (Log) & $\begin{array}{c}-0.134^{*} \\
(2.40)\end{array}$ & $\begin{array}{c}-0.160^{* *} \\
(2.82)\end{array}$ & $\begin{array}{c}-0.056^{* *} \\
(2.92)\end{array}$ & \\
\hline Distance from home greater than zero (Dummy) & $\begin{array}{l}-0.166^{* *} \\
(4.99)\end{array}$ & $\begin{array}{c}-0.158 * * \\
(4.83)\end{array}$ & & \\
\hline Plot size (Log) & $\begin{array}{l}-0.013 \\
(0.74)\end{array}$ & $\begin{array}{l}-0.013 \\
(0.76)\end{array}$ & & \\
\hline Length of plot ownership (Log years) & $\begin{array}{l}0.009 \\
(0.36)\end{array}$ & $\begin{array}{l}0.010 \\
(0.39)\end{array}$ & $\begin{array}{l}0.009 \\
(1.39)\end{array}$ & $\begin{array}{l}-0.001 \\
(0.19)\end{array}$ \\
\hline Plot rented in (Dummy) & $\begin{array}{l}-0.089 \\
(1.61)\end{array}$ & $\begin{array}{c}-0.105^{*} \\
(2.03)\end{array}$ & & \\
\hline Plot purchased (Dummy) & $\begin{array}{l}-0.054 \\
(0.79)\end{array}$ & $\begin{array}{l}-0.059 \\
(0.86)\end{array}$ & & \\
\hline Female-headed household (Dummy) & $\begin{array}{c}0.113^{* *} \\
(2.79)\end{array}$ & & & \\
\hline Married female head (Dummy) & & $\begin{array}{l}0.004 \\
(0.06)\end{array}$ & & \\
\hline Separated female head (Dummy) & & $\begin{array}{c}0.515^{* *} \\
(3.38)\end{array}$ & & \\
\hline Widow female head (Dummy) & & $\begin{array}{l}0.125^{*} \\
(2.53)\end{array}$ & & \\
\hline Conflict pending in 1996-1998 (Dummy) $\delta$ & & & $\begin{array}{l}0.052^{*} \\
(2.55)\end{array}$ & $\begin{array}{l}0.050^{*} \\
(2.41)\end{array}$ \\
\hline Conflict pending in 1999-2001 (Dummy) $\varphi$ & & & $\begin{array}{c}0.167 * * \\
(7.19)\end{array}$ & $\begin{array}{c}0.162 * * \\
(7.03)\end{array}$ \\
\hline Observations & & & & \\
\hline Log likelihood & 112.52 & 120.52 & 126.48 & 117.44 \\
\hline Pseudo R-square & 0.23 & 0.25 & 0.15 & 0.13 \\
\hline $\begin{array}{l}\text { Equality test of the parameters } \\
\chi^{2}(1)\end{array}$ & & & $\begin{array}{l}\delta=\varphi \\
31.76\end{array}$ & $\begin{array}{l}\delta=\varphi \\
30.63\end{array}$ \\
\hline
\end{tabular}

Note: Variables on households and farm assets and regional dummies are included but not reported.

Absolute value of $z$ statistics in parentheses

* significant at $5 \% ; * *$ significant at $1 \%$ 
Table 5: Plot productivity per acre: OLS and IV estimates

\begin{tabular}{|c|c|c|}
\hline & OLS & IV \\
\hline Cultivated land size in acres (Log) & $\begin{array}{c}-0.478^{* *} \\
(7.58)\end{array}$ & $\begin{array}{c}-0.428 * * \\
(5.62)\end{array}$ \\
\hline Family size (Log) & $\begin{array}{l}0.076 \\
(0.86)\end{array}$ & $\begin{array}{l}0.145 \\
(1.41)\end{array}$ \\
\hline Use of chemical inputs (Dummy) & $\begin{array}{c}0.486^{* *} \\
(2.61)\end{array}$ & $\begin{array}{c}0.626^{* *} \\
(2.75)\end{array}$ \\
\hline Conflict pending on plot (Dummy) & $\begin{array}{c}-0.334^{*} \\
(2.31)\end{array}$ & $\begin{array}{c}-2.360^{*} \\
(2.11)\end{array}$ \\
\hline Reason for conflict: exceeding boundaries (Dummy) & $\begin{array}{l}-0.120 \\
(0.88)\end{array}$ & $\begin{array}{l}0.552 \\
(1.46)\end{array}$ \\
\hline Reason for conflict: tenancy (Dummy) & $\begin{array}{l}0.144 \\
(0.88)\end{array}$ & $\begin{array}{l}1.164^{*} \\
(2.01)\end{array}$ \\
\hline Reason for conflict: use of public land (Dummy) & $\begin{array}{l}0.625 \\
(1.61)\end{array}$ & $\begin{array}{l}1.899 * \\
(2.31)\end{array}$ \\
\hline Household had plot for free (Dummy) & $\begin{array}{l}0.011 \\
(0.10)\end{array}$ & $\begin{array}{l}0.045 \\
(0.37)\end{array}$ \\
\hline Household have a house on plot (Dummy) & $\begin{array}{l}-0.091 \\
(0.76)\end{array}$ & $\begin{array}{l}-0.040 \\
(0.28)\end{array}$ \\
\hline Wife and husband cultivate plot (Dummy) & $\begin{array}{c}0.347^{* *} \\
(3.29)\end{array}$ & $\begin{array}{l}0.266^{*} \\
(2.15)\end{array}$ \\
\hline Household have coffee on plot (Dummy) & $\begin{array}{l}0.240 \\
(1.83)\end{array}$ & $\begin{array}{l}0.140 \\
(0.89)\end{array}$ \\
\hline Household have mangoes on plot (Dummy) & $\begin{array}{l}-0.141 \\
(1.20)\end{array}$ & $\begin{array}{l}-0.196 \\
(1.45)\end{array}$ \\
\hline Household have bananas on plot (Dummy) & $\begin{array}{l}0.067 \\
(0.56)\end{array}$ & $\begin{array}{l}0.135 \\
(0.96)\end{array}$ \\
\hline Number of cattle (Log) & $\begin{array}{c}0.425^{* *} \\
(3.86)\end{array}$ & $\begin{array}{c}0.349 * * \\
(2.71)\end{array}$ \\
\hline Number of goats (Log) & $\begin{array}{l}-0.112 \\
(1.06)\end{array}$ & $\begin{array}{l}-0.171 \\
(1.35)\end{array}$ \\
\hline Number of poultry (Log) & $\begin{array}{l}0.121 \\
(0.93)\end{array}$ & $\begin{array}{l}0.091 \\
(0.61)\end{array}$ \\
\hline Number of pigs (Log) & $\begin{array}{c}0.697 * * \\
(5.13)\end{array}$ & $\begin{array}{c}0.590 * * \\
(3.70)\end{array}$ \\
\hline Bad soil quality (Dummy) & $\begin{array}{c}-0.265^{*} \\
(2.50)\end{array}$ & $\begin{array}{l}-0.222 \\
(1.81)\end{array}$ \\
\hline Tenure status: plot rented (Dummy) & $\begin{array}{l}-0.336 \\
(0.64)\end{array}$ & $\begin{array}{l}-0.280 \\
(0.48)\end{array}$ \\
\hline Households with access to credit in village (Percentage) & $\begin{array}{l}0.031 \\
(0.20)\end{array}$ & $\begin{array}{l}0.249 \\
(1.22)\end{array}$ \\
\hline East (Dummy) & $\begin{array}{c}-0.766^{* *} \\
(4.29)\end{array}$ & $\begin{array}{l}-0.383 \\
(1.45)\end{array}$ \\
\hline Center (Dummy) & $\begin{array}{c}-0.769 * * \\
(4.95)\end{array}$ & $\begin{array}{c}-0.448^{*} \\
(2.00)\end{array}$ \\
\hline West (Dummy) & $\begin{array}{c}4.177 * * \\
(15.94)\end{array}$ & $\begin{array}{l}3.938 * * \\
(12.82)\end{array}$ \\
\hline Constant & $\begin{array}{c}-0.478 * * \\
(7.58) \\
\end{array}$ & $\begin{array}{l}0.552 \\
(1.46) \\
\end{array}$ \\
\hline $\begin{array}{l}\text { No. of Observations }{ }^{+} \\
\text {R-squared }\end{array}$ & $\begin{array}{l}818 \\
0.24\end{array}$ & $\begin{array}{l}800 \\
0.05\end{array}$ \\
\hline
\end{tabular}

${ }^{+} 43$ plots with no output or owned land were excluded (51.35\% of these plots have no conflicts pending)

Absolute value of $t$ statistics in parentheses

$*$ significant at $5 \% ; * *$ significant at $1 \%$ 
Figure 1. Locally weighted regressions of land productivity.

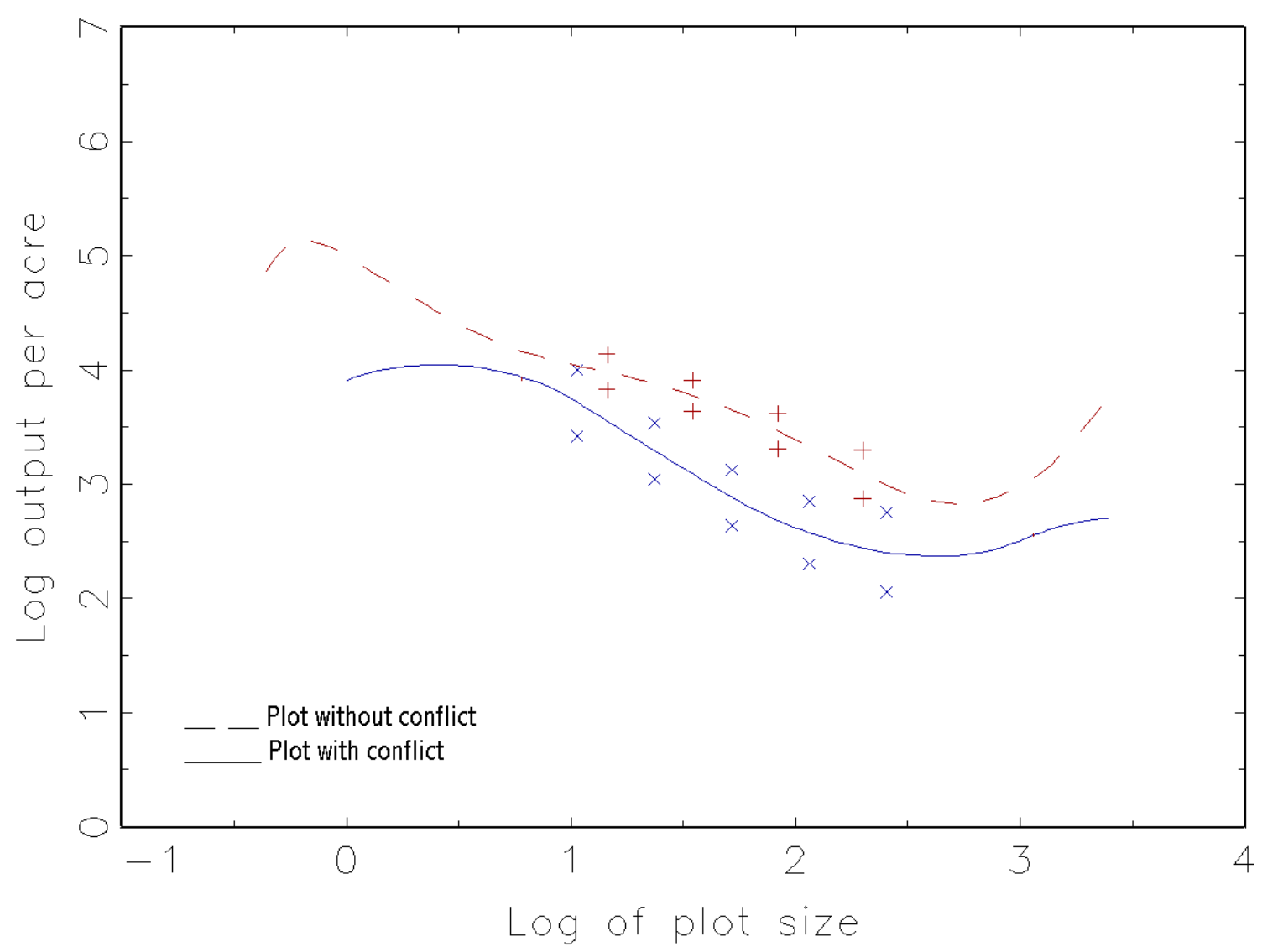


References:

Alden-Wily, L. 2002. "Comments on the Legal Basis for Land Administration in an African Context." World Bank Regional Land Policy Workshop in Kampala, Uganda.

Amanor, K. S. and M. K. Diderutuah. 2001. Share Contracts in the Oil Palm and Citrus Belt of Ghana. London: International Institute for Environment and Development, and Groupe de Recherche et d'Echange Tecnologiques.

Andre, C. and J. P. Platteau. 1998. "Land Relations under Unbearable Stress: Rwanda Caught in the Malthusian Trap." Journal of Economic Behavior and Organization 34 (1): 1-47.

Angrist, J. D. 1991. "Instrumental Variables Estimation of Average Treatment Effects in Econometrics and Epidemiology." National Bureau of Economic Research Technical Paper: 115.

Atwood, D. A. 1990. "Land Registration in Africa: The Impact on Agricultural Production." World Development 18 (5): $659-71$.

Barzel, Y. 2000. "Dispute and Its Resolution: Delineating the Economic Role of the Common Law." American Law and Economics Review 2 (2): 238-58.

Benjamin, D. 1995. "Can Unobserved Land Quality Explain the Inverse Productivity Relationship?" Journal of Development Economics 46 (1): 51-84.

Berry, S. 1997. "Tomatoes, Land and Hearsay: Property and History in Asante in the Time of Structural Adjustment." World Development 25 (8): 1225-41.

Bhalla, S. S. and P. Roy. 1988. "Misspecification in Farm Productivity Analysis: The Role of Land Quality." Oxford Economic Papers 40 55-73.

Binswanger, H. P., K. Deininger and G. Feder. 1995. "Power, Distortions, Revolt and Reform in Agricultural Land Relations." Handbook of development economics. Volume 3B (1995): 2659-772.

Blake, A., A. McKay and O. Morrissey. 2002. "The Impact on Uganda of Agricultural Trade Liberalisation." Journal of Agricultural Economics 53 (2): 365-81.

Boserup, E. 1965. Conditions of Agricultural Growth: The Economics of Agrarian Change Under Population Pressure. New York: Aldine Publishing Co.

Brett, E. A. 1973. Colonialism and Underdevelopment in East Africa: The Politics of Economic Change, 1919-1939. London: Heineman.

Chauveau, J.-P. 2000. "Question Fonciere et Construction Nationale en Cote d'Ivoire." Politique Africaine 78 94-125.

Daudelin, J. 2002. "Land as a Source of Conflict and in Post-Conflict Settlement." World Bank Regional Workshop on Land Issues in Africa and the Middle East, April 29-May 2, 2002, Kampala, Uganda.

Deininger, K.and J. Okidi. 2001. "Rural Households: Incomes, Productivity, and Nonfarm Enterprises." In Collier, P. and R. Reinikka, eds., Uganda's recovery: The role of farms,firms, and government; Oxford University Press.

Deininger, K. 2003. Land Policies for Growth and Poverty Reduction. A World Bank Policy Research Report. Oxford and New York: World Bank and Oxford University Press.

Deininger, K. and G. Feder. 2001. "Land Institutions and Land Markets." Handbook of Agricultural Economics (B.Gardner and G.Raussser, Eds) 288-331.

Fan, J. 1992. "Design-adaptive Nonparametric Regression." Journal of American Statistical Association 87 (420): 998-1004.

Fan, J. and I. Gijbels. 1996. Local Polynomial Modeling and Its Applications Chapman and Hall.

Firmin-Sellers, K. 2000. "Custom, Capitalism, and the State: The Origins of Insecure Land Tenure in West Africa." Journal of Institutional and Theoretical Economics 156 (3): 513-30.

Fred-Mensah, B. K. 1999. "Capturing Ambiguities: Communal Conflict Management Alternative in Ghana." World Development 27 (6): 951-65.

Frisvold, G. B. 1994. "Does Supervision Matter? Some Hypothesis Tests using Indian Farm-Level Data." Journal of Development Economics 43 (2): 217-38.

Gilborn, L. Z., R. Nyonyintono, R. Kabumbuli, and G. Jagwe-Wadda. 2000. "Making a Difference for Children Affected by AIDS: Baseline Findings from Operations Research in Uganda." . Washington, DC: Population Council.

Government of Uganda. 1999. "Report of the Land Act Implementation Study." . Kampla: Ministry of Land, Water, and Environment.

Government of Uganda. 2003. "Uganda: Issues and Challenges for National Land Policy." . Kampla: Governance Resource Center.

Grossman, H. I. and J. Mendoza. 1998. "Scarcity, Abundance, and Appropriative Conflict." Brown University, Department of Economics Working Paper: 98/12. 
Hoxby, C. M. 1996. "How Teachers' Unions Affect Education Production." Quarterly Journal of Economics 111 (3): 671-718.

Kairaba, A. 2002. "Country Case Study: Rwanda." World Bank Regional Workshop on Land Issues in Africa and the Middle East, April 29-May 2, 2002, Kampala, Uganda.

Kasanga, K. and N. Kotey. 2001. Land Management in Ghana: Building on Tradition and Modernity. London: IIED.

Kevane, M. and L. C. Gray. 1999. "A Woman's Field Is Made at Night: Gendered Land Rights and Norms in Burkina Faso." Feminist Economics 5 (3): 1-26.

Khadiagala, L. S. 2001. "The Failure of Popular Justice in Uganda: Local Councils and Women's Property Rights." Development and Change 32 (1): 55-76.

Kriger, N. J. 1992. Zimbabwe's Guerrilla War, Peasant Voices. Cambridge: Cambridge University Press.

Kuran, T. 1993. "Sparks and Prairie Fires: A Theory of Unanticipated Political Revolution." 273-306 Witt, Ulrich .

Lavigne Delville, P. 2000. "Harmonising Formal Law and Customary Land Rights in French-Speaking West Africa." In Toulmin, C. and J. Quan, eds., Evolving land rights, policy and tenure in Africa. London: DFID/IIED/NRI.

Lavigne Delville, P., C. Toulmin, J.-P. Colin and J.-P. Chauveau. 2002. Negotiating Acces to Land in West Africa: A Synthesis of Findings from Research on Derived Rights to Land. London: IIED/GRET.

Lavigne-Delville, P. 2002. "Customary To Modern Transition." World Bank Regional Land Workshop in Kampala, Uganda.

Makerere Institute of Social Research. 2002. "The Justification for Co-Onwership of Land by Spouses: A Qualitative Perspective ." In Rugadya, M. and H. Busingye, eds., Gender Perspectives in the Land Reform Process in Uganda. Kampala, Uganda: Uganda Land Alliance.

Mijumbi, P. and A. Sebina-Zziwa. 2001. "Case Studies on Land Conflict." . Kampla: Econmic Policy Research Center.

Moore, B. 1966. Social Origins of Dictatorship and Democracy: Lord and Peasant in the Making of the Modern World. Boston: Beacon Press.

Mugisha, O. R. 1998. Uganda Districts Information Handbook. Kampala: Fountain Publishers.

Ngaido, T. and N. McCarthy. 2002. "Pastoral Land Rights." World Bank Regional Land Workshop in Kampala, Uganda.

Ntozi, J. P. M.and F. E. Ahimbisibwe. 1999. "Some Factors in the Decline of AIDS in Uganda." In Caldwell, J. C., I. O. Orubuloye and J. O. M. Ntozi, eds., The continuing African HIV/AIDS Epidemic. Canberra: Health Transition Centre, National Centre for Epidemiology and Population Health, Australian National University.

Oosterberg, T. 2002. "Designing Viable Land Administration Systems." World Bank Regional Land Workshop in Kampala, Uganda.

Perali, F. 2003. "The Behavioral and Welfare Analysis of Consumption. Evidence from Colombia." Kluwer Academic Publisher Dordrecht.

Pierret, C. R. 2001. "Event History Data and Survey Recall: An Analysis of the National Longitudinal Survey of Youth 1979 Recall Experiment." Journal of Human Resources 36 (3): 439-66.

Pinckney, T. C. and P. K. Kimuyu. 1994. "Land Tenure Reform in East Africa: Good, Bad or Unimportant?" Journal of African Economies 3 (1): 1-28.

Platteau, J. P. 2000. Institutions, Social Norms, and Economic Development Fundamentals of Development Economics, vol. 1. Reading, U.K.: Harwood Academic.

Schultz, T. P. 1999. "Women's Role in the Agricultural Household: Bargaining and Human Capital." Economic Growth Center, Yale University Discussion Paper \#803.

Sjaastad, E. and D. W. Bromley. 2000. "Indigenous Land Rights in Sub-Saharan Africa: Appropriation, Security and Investment Demand." World Development 25 (4): 549-62.

van den Brink, R., D. W. Bromley and J. P. Chavas. 1995. "The Economics of Cain and Abel: Agro-pastoral Property Rights in the Sahel." Journal of Development Studies 31 (3): 373-99.

van Donge, J. K. 1999. "Law and Order as a Development Issue: Land Conflicts and the Creation of Social Order in Southern Malawi." Journal of Development Studies 36 (2): 48-70.

Wickham-Crowley, T. 1991. Exploring Revolution: Essays on Latin American Insurgency and Revolutionary Theory. Armonk, NY: M.E.Sharpe.

World Bank. 2002. World Development Indicators 2002. Washington, DC: World Bank.

Yatchew, A. 1999. "An Elementary Nonparametric Differencing Test of Equality of Regression Functions." Economics Letters 62 (3): 271-8.

Zongo, M. 2002. "Land Conflict." World Bank Regional Land Workshop in Kampala, Uganda. 